\title{
The Danish Income-Cap Regulation in the Power Supply Sector: A Legal Perspective Considering the Green Transition
}

\author{
Bent Ole Gram Mortensen \\ University of Southern Denmark
}

\begin{abstract}
The break-even principle has been a fundamental principle for the price regulation of the Danish utilities for several decades. Following the liberalization of parts of the energy sector, this regulation has been supplemented with new instruments to regulate monopoly areas. This form of regulation was introduced in connection with a new electricity supply regulation from 1999. The detailed design of the income-cap regulation has been left to the Minister responsible for the energy sector and the supervisory authority (currently the Danish Utility Regulator). Income-cap regulation of power grids has given rise to several challenges. Thus, the specific design of the revenue framework has been changed several times. At the same time, however, some experience has been gained with the administrative handling of this form of regulation. Several cases have, in the absence of administrative courts in Denmark, been dealt with by the Danish Energy Board of Appeals. Since the introduction of revenue frameworks, the power (electricity) sector has changed. Furthermore, the sector must adapt to the Green Transition, which will require capacity expansion at both transmission and distribution levels, or other measures must be taken to prevent bottlenecks in the system. In this paper the income-cap experience will be discussed.
\end{abstract}

KEYWORDS: Income-cap, Grid Companies, Green Transition, Electricity, Power Supply, Utilities

\section{INTRODUCTION}

In the following, the income-cap regulation in Danish utility legislation will be discussed in light of the Green Transition. Income caps have been applied to utilities in Denmark for a long time. First they were introduced for the power distribution grids. Later they were implemented in the water sector, and it has been suggested that they be implemented within the district heating sector.

In sections 4 and 5 the methods and scope are accounted for. In sections 6 and 7 the historical background and the actual distribution network are explained for the sake of understanding. In sections 8-11 the actual price regulation is discussed, including the practice of the Energy Board of Appeals (EBA). Section 12 concludes regarding the current income-cap regulation and its suitability in relation to the Green Transition.

It is recommended to consider keeping the extraordinary investments connected to the Green Transition outside the income-cap regulation, to consider technical requirements for EV charge points and heat pumps, so that these can be part of a smart grid system, and to consider whether solar panels should be banned in neighbourhoods with weak networks.
This article does not provide a complete assessment of the rules regarding income-cap regulation. This is not necessary given the purpose of the article, and it is assumed that the readers of this article are acquainted with the income-cap regulation.

The power supply must now adapt to the Green Transition, which will require capacity expansion at both transmission and distribution levels, or other measures to prevent bottlenecks in the system. This paper will discuss to what extent the Danish income-cap regulation contains elements that support the Green Transition.

The Danish Energy Regulatory Authority was renamed the Danish Utility Regulator (DUR) in 2018. In order to improve readability, the regulatory authority will be referred to as the Danish Utility Regulator even in cases from before 2018.

\section{METHOD}

This article is a jurisprudential contribution to the discussion about the Green Transition. Other scientific approaches are not included in general. The purpose of this contribution is not to outline an economic exposition of the economic models that underlie the calculation of the specific in-come caps. 
The primary assessment is based upon a dogmatic legal approach regarding the former practice of the application of income-gap regulation. It is preferential to emphasize cases that have been tried at the administrative board of appeals (EBA) in recognition of the fact that the Danish Utility Regulator's rulings are often tried here and not in the courts of justice.

\subsection{IDENTIFICATION OF CASES}

Regarding the identification of relevant cases, a search has been run on the Energy Board of Appeals' public website. A search for the term "in-comecap" (in Danish "indtægtsramme") returned 71 hits, and all of these have been examined. Some of the hits relate to multiple cases, where more than one case has been treated in the same ruling. For instance, EBA file number 1011-11-26 concerns a complaint from 58 different electricity grid companies. Some of the hits concerned cases that are irrelevant in this context, such as income-caps for natural gas distribution companies.

One case (EBA file number 18/00359) has been retrieved from another source. This case did not emerge through the search mentioned. It cannot be guaranteed that no other cases exist.

To ensure the quality of the selection of relevant cases, a formal application for access to documents has been filed to the Energy Board of Appeals, which was answered with a similar search on the official web-site. It is presumed that the internal journalizing system at the Energy Board of Appeals has not been used. For this reason, it is not possible to say anything about the total number of cases that have passed the Energy Board of Appeals concerning income caps. No further inquiries have been made to the Energy Board of Appeals regarding searches directly in the Energy Board of Appeals' journaling system.

\subsection{LIMITATIONS}

Please note that much of the Danish legal material is not available in official or unofficial translations into English. My own translation of legal texts has therefore been widely used. Assessment of documents et cetera that were originally written in Danish has been reviewed and analysed in the original language.

The main part of the analysis has, as mentioned above, been based on cases from the Energy Board of Appeals. Since there is a certain processing time at the Energy Board of Appeals, the selected cases originate from financial years regulated by older versions of the present income- cap executive order. Thus, the experiences do not concern the latest version of the income-cap regulation. Some cases have been appealed to the Energy Board of Appeals since the latest income-cap executive order was issued. Decisions in these cases have not yet been made.

\section{SCOPE}

This article focusses on income-cap regulation of the Danish electricity distribution network and experience with its administration. The choice is based on the fact that there are a several decades of experience with this price regulation instrument as far as electricity distribution networks are concerned. Furthermore, there exist a number of rulings from both the Danish Utility Regulator and the Energy Board of Appeals (and previous authorities), which provide a better basis for interpretation.

Other price regulation mechanisms are not analysed and are only mentioned briefly.

Income-cap regulation is only considered in relation to the electricity distribution network. Income-cap regulation can also be applied to other networks. Most recently, a proposal has been issued for consultation concerning the Transmission System Operator (TSO) and electricity transmission companies - in Denmark these are gathered in a state-owned company: Energinet (bill No. L 115 of 26 February 2020 regarding amendments to the Danish Energy Net Act).

\section{HISTORICAL BACKGROUND}

Electricity supply began its distribution in the market towns in the late 1800 s. Originally, there was no sector specific price regulation. In fact, the Danish electricity supply system was originally self-organised with next to no legislative regulation or state involvement. However, electricity supply was included in the more general regulation in the Monopoly Act (1955) and the Price and Profits Act (1974). However, this regulation covered only private business enterprises and thus not the municipal energy supply companies (Mortensen 2002, p. 15).

The municipal electricity, gas and heat companies were regulated in accordance with the general municipal regulations for utilities. The municipal electricity sector was governed by a break-even principle (Olsen 1999, p. 100).

Act no. 54 of 25 February 1976 on Electricity Supply (the 1976 act) implemented the first general independent price regulation of the utilities in the electricity sector.

Corresponding Law No. 258 of 8 June 1979 on Heat Supply implemented a regulation of the heat and natural gas utilities.

In the Electricity Supply Act (1976) and Heat Supply Act (1979), the price regulations were implemented as almost identical regulations that enumerated the expenses which the regulated companies could include in their prices. The distribution companies at the time, mainly owned by the municipalities or consumers in the form of co-operative societies, owned the production companies jointly on a partnership or co-operative basis. The pricing principles had the character of price-cap regulation, and the electricity companies (not unbundled then) were intended to be economically self-sustained (L234/1999, section 1.5).

The central term, necessary expenses, was an expression of a legal standard originating in monopoly and price regulation (Mortensen 2002, p. 104). The term is still included in the price regulation of district heating but was abolished for power distributions grids in $2017 .{ }^{1}$ 
In addition, a regulator (then Elprisudvalget) was given the power to intervene under the Electricity Supply Act (1976) in cases where prices or other conditions were unreasonable or out-of-step with the provisions of the law (Mortensen 2002, p. 48 ff.). This concept came from the Monopoly Act and continues to apply in the price regulation of district heating and for power distributions grids.

Income-cap regulation was implemented with the new Electricity Supply Act of 1999 (Act No. 375 of 2 June 1999). The income-cap regulation was introduced at the same time as a reorganization of the electricity sector, which was split into independent legal entities. At the same time, however, no ownership unbundling of the electricity grid companies was introduced. Thus, economic interest-based partnerships with commercial parts of the electricity sector (trade and production) and distribution grids still exist in the form of holding structures. The level of unbundling is still up to discussion, and it is a question whether the present Danish regulation regarding this is sufficient (Danish Utility Regulator, 2019). In a time of Green Transition, it is important to "protect" the grid against interests which may not support such a transition.

The detailed design of the 1999 income-cap regulation was left to the Minister responsible (currently the Minister of Climate, Energy and Utilities) and to the supervisory authority (currently the Danish Utility Regulator - DUR). In the subsequent period, the framework has changed. This applies to the foundation of the Electricity Supply Act and the changing income-cap Acts, as well as the underlying methods that the Danish Financial Supervisory Authority uses as support to determine efficiency requirements. There have now been several income-cap acts for network companies:

- Executive Order no. 944 of 29 October 2001.

- Executive Order no. 432 of 6 June 2002.

- Executive Order no. 1148 of 15 December 2003.

- Executive Order no. 899 of 30 August 2004.

- Executive Order no. 1520 of 23 December 2004.

- Executive Order no. 151 of 10 March 2005.

- Executive Order no. 1027 of 2 November 2009.

- Executive Order no. 1227 of 10 December 2009.

- Executive Order no. 1294 of 24 November 2010.

- Executive Order no. 335 of 15 April 2011.

- Executive Order no. 195 of 4 March 2016.

- Executive Order no. 857 of 28 June 2017.

- Executive Order no. 1594 of 18 December 2017.

- Executive Order no. 969 of 27 June 2018.

- Executive Order no. 1366 of 28 November 2018.
As seen from the list above, the income-cap regulation has been developed continuously. It has not been a finished concept that has been rolled out over the electricity distribution networks. And the list above does not include changes in benchmarking macros.

The reason for the many changes must be found in the problems that arose in connection with the application of income-cap regulation to the electricity sector. The first attempts led to income-caps significantly above the previous price level. The purpose of the revenue framework was to create incentives for efficiency gains. This was expected to be achieved through increased transparency, pressure to reduce costs to avoid allowable revenues being lower than costs and the possibility of a profit. However, the regulation did not result in a tight revenue framework which could pressure companies to become more efficient, but led to unintended incentives - overinvestments, i.e. greater investment and maintenance of the networks.

In addition, it proved difficult to design a well-functioning and credible benchmarking model. Capture and information asymmetry became relevant (Sørensen 2012, p. 25).

\section{ABOUT THE PRESENT DANISH POWER DISTRIBUTION GRIDS}

The service supplied by a distribution power grid covers not only energy transport to a costumer. It also covers availability of electrical energy at whatever time consumers need it. Therefore, the network must be capable of handling peak loads. The network's maximum capacity and thus the required investments depend on how high the peaks are in the consumption patterns.

It is assumed that the Danish electricity distribution network has a total length of approximately $159,000 \mathrm{~km}$ (Energinet 2020, p. 19). The distribution network is owned by several network companies. These act as the Distribution System Operators (DSOs) according to EU energy law, especially chapter IV of the electricity directive.

Under section 19 of the Electricity Supply Act, a network company is required to have a licence granted by the Minister (Mortensen and Rønne 2016, Part I, ch. 7, \$1).

Further, Danish legislation provides for requirements that are intended to separate monopolistic undertakings from undertakings that are exposed to competition (unbundling). See section 45 and 47 of the Electricity Supply Act (Mortensen and Rønne 2016, Part I, ch. 2).

The demands on the distribution network have been changing in recent years. This development has been on the way for some time. A movement towards more decentralized and fluctuating production (increased amount of sun and wind, partly as distributed generation) and a change in the consumption pattern with more heat pumps and electric cars. There is a need for investments in the network (qualitative and quantitative). Please note that grid investments are sunk costs.

The transition must be expected to become a challenge for the income-cap regulation. The grid can be expanded so that it can handle peak load demand for consumption, as well as the maximum need in relation to fluctuating production from sun and wind. Electricity is basically a flow of charge carried by free-flowing electrons and the grid 
needs to be in balance all the time. Storage is expensive. From a legal perspective, electricity is considered a product. In Case 6/64, Costa v ENEL, electricity was presumed to be a good. In relation to Article 34 TFEU [then Article 28], this was confirmed by the Court of Justice in Case C-393/92, Almelo and others vs. Energiebedrijf Ijsselmij, para. 28, which refers to the Union's tariff nomenclature (code CN 27.16).

However, such an expansion can be expected to be expensive (overinvestment), especially considering that a large part of the investment in physical expansion of the grid can be replaced by other measures, such as moving electricity consumption away from peak load and implementing a more efficient location of wind turbines and solar panels in relation to grid capacity and consumption. The present location policy based on municipality planning has already resulted in a localization imbalance between consumption and production. The expected expansion with solar panels on agricultural land will only aggravate the situation

\section{PRICE REGULATION IN GENERAL}

In Denmark, the price for producing electricity is governed by free-market conditions, both wholesale and retail. The price regulation analysed in this paper relates to the distribution network that ensures the transportation of electricity to end consumers. Price regulation on the distribution network is not only a question of ensuring effective operation, but also of providing the correct incentives for investments in the network. The problems described above illustrate the issue.

Tariffs for using the power distribution network have for many years been covered by pricing regulations. The regulation reflects the fact that an electricity network is a natural monopoly. The price regulation is intended to protect customers tied to monopoly suppliers from exploitation. Natural monopolies are characterized by expenses for the necessary infrastructure of such a prohibitive size that due to economies of scale, cost-effectiveness can only be achieved with one set of installations through which the task is carried out. Different definitions exist. In there is an alternative cost-related definition: "By a natural monopoly we mean an industry whose cost function over some given set of products is such that no combination of several firms can produce an industry output vector as cheaply as it can be provided by a single supplier Baumol et al (1977, p. 350-365).”

Further, electricity supply is among the utility outputs that can be perceived as necessary without evident substitutes for the consumers (Olsen and Smidt 2012).

It is the network company that determines the amount of payment for use of a distribution network (the tariff) (Mortensen and Rønne 2016, Part I, ch. 7, \$4). The Electricity Supply Act gives each electricity grid company leeway to choose a tariffing scheme, as long as this is within the scope of the Electricity Supply Act (EBA file number 11-161). Section 73 of the Electricity Supply Act, in particular, determines the overall framework that tariffs must be based on a variety of fundamental requirements, according to which tariffs must be reasonable, objective and non-discriminatory, and they must reflect the true costs. The requirement for reasonable pricing dates back to the first Electricity Supply Act in 1976, and the terms 'objective' and 'non-discriminatory' are taken from the Electricity Directive.
However, the methods and conditions for calculating the tariff must be notified to and approved by the Danish Utility Regulator, see section $73 a$ and 76 of the Electricity Supply Act.

The main tool regarding price regulation is now an income-cap regulation. However, according to section 77(2-4), the Regulator can amend the prices and conditions if:

- They are in contravention of the provisions of the Electricity Supply Act.

- An unreasonable matter in relation to negotiations concerning grid access cannot be stopped by order pursuant to subsection 1 . The Regulator can issue an order to the licensees in this case to enter into an agreement concerning the matter on the usual current terms for similar agreements.

- The Regulator should find that prices, terms or agreements may be deemed to result in an environmentally or economically inappropriate utilisation of energy, following negotiation with the parties.

- The company has conducted a transaction that cannot be regarded as reasonable vis-à-vis consumers. The Regulator may also decide that a company must utilise profit to amend prices to a specified extent.

The Danish Utility Regulator has announced that no decisions have been made pursuant to section $77(2-4)$.

\section{INCOME-CAP REGULATION}

Income-cap regulation is an indirect form of price regulation. This means no direct requirements for the tariff to be paid by the consumers. On the contrary, this mode of control entails only a limit on the revenue that can be collected from the consumers.

Income-cap regulation is not the only model used on grid companies. For example, a price-cap can be used (tariff ceiling) or a regulation of the rate-of-return (expenses and return on invested capital). Incomecap regulation and rate-of-return regulation are widespread in the nearest countries around Denmark (Deloitte 2013, p. 16).

\subsection{INTRODUCTION OF INCOME- CAP REGULATION IN DENMARK}

Income-cap regulation was implemented by the Electricity Supply Act from 1999. In the general remarks to the bill (bill no. L 234 of 29 April 1999), in paragraph $2 \mathrm{i}$ the purpose is specified: "The purpose of price regulation of grid and transmission activity is to create incentives for increased efficiency". Efficiency is the main goal.

Furthermore, it is specified that: "The framework will be established in such a way that the framework for the revenue of a company is to be reduced each year, so that each company will have to implement on-going efficiency improvements to keep their costs within the framework of revenue." And it is an ongoing process. 
Soon after the 1999 Electricity Supply Act, regulations on income-cap were implemented in the Natural Gas Supply Act and the Heat Supply Act. The latter of the two did not result in the actual determination of income-caps. The regulation in section 20a of the Heat Supply Act was removed again in 2017 but is now on the political agenda again.

In 2017, another shift in the application of income regulation for net companies occurred. The old regulations regarding necessary expenses were removed. ${ }^{2}$ The present framework control now focuses on income-cap as the primacy means of regulation.

It appears from the preparatory work for the 2017 law that revision of price regulation was based on recommendations from the 'Regulation Commission' (bill No. L 180 of 29 March 2017 regarding amendment to the Danish Energy Supply Act, section 3.1.2.1.1, among others).

The regulation committee acknowledged that a reorganization of the distribution network was necessary. A couple of statements testify to this and the Green Transition:

- "The distribution network must be developed to be able to support the Green Transition, including the establishment of smart grids and new functionalities." (Regulation Commission of the Danish Parliament 2014, p. 32).

- "The grid companies are facing a future where the timing and extent of local production and consumption is more unpredictable due to, among other things, fluctuating energy sources and the possibilities for moving consumption and increased awareness of market opportunities among customers. In other words, the demand for network services is expected to become increasingly differentiated from one customer to the next. In order to be able to adapt to this reality, there will be a need, among other things, for the network companies to initiate investments in Smart Grids as the need arises and the development continues with dynamic tariffs." (Regulation Commission of the Danish Parliament 2014, p. 25).

An adaptation to what is now required in connection with a Green Transition is thus nothing new. It should already be included in the income-cap regulation.

\subsection{PRESENT INCOME-CAP EXECUTIVE ORDER}

The current income-cap regulation originates from 2018. See Danish Utility Regulator 2020, p. 18. Basically, the regulation entails that the Danish Utility Regulator must announce an income-cap which accounts for the largest amount of money that a network company may receive as income from the operation of the network company's licensed activity in a calendar year. The income-cap consists of the total of an expense frame and a rate of return cap. These frames are based on a model in which monetary adjustments are made according to individual circumstances.

The expense frame is defined in section 6 of the executive order as "the average expenses in the former regulation period". An element of historical expenses is involved in the determination of income-caps. This means one gets the most generous income-cap if one enters the regulation with the highest expense level. There may be an incentive to maintain the maximum expense level for future regulation years, to have the expense frame reduced.

The rate of return frame that is addressed in section 7 provides an opportunity to earn interest on an amount that is considered equity in the network company. This part of the income-cap has a background in an agreement from 2004 between the minister in charge and the electricity sector (ELFOR-agreement 2004). The unusual agreement determines that the network companies were given the right to freely dispose of their equity in exchange for the transmission network being transferred to the state free of charge. Therefore, the owners of the network companies have had the opportunity to withdraw funds and profits from the network companies (Danish Utility Regulator 2020, p. 3-4). The rate of return frame will not be addressed further.

Pursuant to section 5(1)(1-6) of the income-cap executive order, the income-cap is adjusted for several circumstances. Furthermore, the executive order enumerates some circumstances in chapter 5 that can result in an upward adjustment of the income-cap. Most of the adjustments under chapter 5 are only carried out after application. It is assumed that a network company will only apply for upward adjustment. For the first regulation period, there also is a transition period in section 56. However, in certain cases, the Danish Utility Regulator must reduce the expense frame and the return basis on its own initiative, cf. sections 24-26, section 28 and section 30 .

The income-cap regulation does not contain a ceiling for how large an efficiency requirement a company can be faced with in a single year, or possibly also accumulate over several years. Thus, according to the rules, it is not enough for the grid companies to reduce their costs by the efficiency potential that can be calculated at any given time. The companies must be subjected to a comparison with each other every year, with the result that new efficiency requirements may be announced for the companies that are not the most efficient, as the assumption is that the companies will be able to constantly reduce their costs through further efficiency improvements. It is doubtful whether such efficiency requirements based on benchmarks will make sense in a situation where the grid companies have to make very different investments in connection with the Green Transition.

The data for determining the income-cap comes from the grid companies. It follows from section 2 of Executive Order no. 902 of 26 June 2018 on Network Companies' Regulatory Accounts, that network companies must annually report a regulatory account to the regulator.

\section{OBLIGATION TO MAKE A COMPLETE TRIAL}

The Energy Board of Appeals undertakes a complete trial of the submitted cases in general. This is in accordance with the general starting point for administrative legal recourse authority, even though in practice the trial intensity of the different legal recourse authorities can differ (Mortensen and Hamer 2020, p. 368 f.). Accordingly, the Energy Board of Appeals trial includes the concrete methods that the Danish Utility Regulator develops. 
An example can be found in EBA file number 1011-13-3-76. Besides controlling the compliance of the general administrative law principles (specifically if the required consultation had occurred), the Energy Board of Appeals entered the control of the Danish Utility Regulator. The Danish Utility Regulator thus determined in its practice regarding announcements of efficiency requirements, that the Danish Utility Regulator had "broad discretion in the benchmarking of the electricity grid companies, and that the method chosen by the Danish Utility Regulator (the grid volume model) must be considered suitable for assessing the electricity grid companies' efficiency, and be otherwise based on objective considerations" (my translation); (see also EBA file numbers 11-273, 11-538, 11-539, 11-540, 1011-331, 1011-15-4 and 18/00211). In EBA file numbers 1011-331, 1011-346, 1011-10-8 and 1011-10-9, the Energy Board of Appeals determined it to be within the Danish Utility Regulator's discretionary power to deselect a correction for price-raising conditions on the west coast (increased corrosion). This means that the Energy Board of Appeals respects the supervisory authority's finding of relevant considerations and balancing them, but partly the legality is tried for the sake of (objectivity), and partly eligibility is tried. Objectivity is a fundamental requirement for the administrative law opinion (Mortensen \& Motzfeldt 2020, p. 278), and eligibility appears increasingly to be an accepted part of proportionality trial (Mortensen \& Motzfeldt 2020, p. 305). In the specific case, the Energy Board of Appeals commented on methods regarding correction for significant price-raising framework conditions (specific customer density). In this part of the ruling, the Energy Board of Appeals commented on the fact that it is necessary with continuous revision of this correction. Also see EBA file number 1011-15-8 regarding the Energy Board of Appeals' acceptance of corrections to customer density. Hence, these benchmarking models are attributed to a more dynamic existence compared to other administrative law rulings in general. In EBA file number 1011-14-52 the Energy Board of Appeals remitted to the Danish Utility Regulator for the purpose of correcting the efficiency requirement by using data from 2011 and 2012 regarding customer density. In EBA file number 1011-277 the Energy Board of Appeals assessed the specific efficiency of using two-year-old data, the incentives of using threshold value (reliability of delivery), and also in general whether methodological or factual errors were demonstrated.

In addition to the aforementioned case's trial of objectivity, eligibility, and consultation, other administrative law requirements are tried in income-cap cases. For example, see EBA file number 1011-405 and 18/00206 (inquisitorial principle) and EBA file number 11-323 (the obligation to state reasons). The above-mentioned principle of proportionality has also been tried in relation to whether setting efficiency requirements, which entails that the income-cap is reduced to a level where the network company cannot be reimbursed for costs of effective operation, should be irregular to the principle of proportionality. The Energy Board of Appeals commented that this was not an expression of effective operation as long as failed efficiency improvements for some years resulted in the reduced income-cap no longer being able to cover expenses. The annual announcements of efficiency requirements were thus not in conflict with either the income-cap Executive Order or the Electricity Supply Act. For example, see EBA file number 1011-15-4. The principle of proportionality has also been addressed in relation to the Danish Utility Regulator's reduction of the efficiency period (EBA file number 1011-346).

Actual errors or misunderstandings of the legislation are corrected by the Energy Board of Appeals. The correction is also a detriment for a complainant. For example, see EBA file number 1011-13-91, where the Energy Board of Appeals, in opposition to the Danish Utility Regulator, did not find a legitimate expectation.

The supervisory authority can specify a deadline for notification. For example, see EBA file number 1011-346, where the Energy Board of Appeals found that the Danish Utility Regulator has the authority to determine deadlines for submission of notifications and documentation. Furthermore, the Energy Board of Appeals found the following objectively justified: Exceeding deadlines for notification and documentation of extraordinary costs in a timely manner may have the effect that they are not included in the determination of the efficiency requirements for the coming year. See also EBA file numbers 1011-1176, 1011-11-78, 1011-11-79, 1011-11-80 and 1011-11-8.

\section{COMPONENTS IN REGULATION ACCOUNT}

The expenses that are covered by a network company's income-cap encompass, according to section 3, item 2 of the current income-cap Executive Order:

1) Depreciation and operating expenses.

2) Return of interest on a historical return basis (income-cap Executive Order section 7 and section 39) and a forward-looking return basis (income-cap Executive Order section 7 and section 40, and also Executive Order no. 1595 of 18 December 2017 on the rate of return for network companies forward-looking return basis), which cf. section 7 .

3) Expenses associated with the implementation of energy efficiency covered by the Executive Order on energy-saving service in network and distribution companies.

The examples below all originate from The Energy Board of Appeals (EBA).

\subsection{NET ASSETS}

A financial incentive has been for the individual network company to maximize its net assets to have a larger economic latitude.

An example of this is seen in a ruling from the Energy Board of Appeals from 2020 (EBA file number 18/03884). In the relevant case, the Danish Utility Regulator had decided "that delivered quantities to electricity consumers directly connected to the transmission network should not be included in the regulation accounts, just as income, costs, depreciation and the value of network assets related to the same electricity consumers should not be included in the regulation accounts" (my translation). This ruling was accepted by the Energy Board of Appeals. The ruling was in line with former practice from the Energy Board of Appeals. See EBA file number 18/00359 (customer relations with consumers directly connected to the transmission network was not covered by a network company's authorization to run a network company), EBA file number 18/00276 (delivered amounts of electricity and also income, expenses, depreciation, and the value of net assets related to customers directly connected to the transmission 
network were not counted in the network company's regulation account), EBA file number 18/00278 (Danish Railway Agency) and EBA file number 18/0027 respectively 1011-17-34 (electricity consumers directly connected to the transmission network should not be factored in the regulation account). It made no difference that the relevant network companies owned the meters and measurement systems.

However, the Energy Board of Appeals came to the opposite conclusion in EBA file numbers $18 / 00279$ and $18 / 00359$. It was determined that delivered amounts of electricity to customers directly connected to the transmission network could be factored in the complainant's regulation accounts. The relevant regulations were substantiated by justified expectations. Justified expectations were tried in EBA file number 18/00281 but were declined.

Another example can be found in EBA file number 18-03884 in which the Energy Board of Appeals confirmed the Danish Utility Regulator's regulation on cars, rolling material and tolls could be characterized as net assets.

\subsection{EXTRAORDINARY EXPENSES}

The income-cap executive order encompasses regulations on adjustment of the economic frame in case of extraordinary circumstances. For example, see the executive order $\$ 18$ (net loss because of exogenous circumstances) and $\$ 32$ (significant negative result because of exogenous circumstances). Earlier versions of the income-cap executive order decisions have been made on extraordinary expenses.

In EBA file number 1011-13-3 from 2012, the Energy Board of Appeals found that the expenses for remotely read meters should be kept out of the benchmarking as extraordinary expenses. Otherwise, the starting point was that all expenses must be included in the benchmarking. The Energy Board of Appeals found that the benchmarking had to be continuously adjusted to technological development. Remotely read meters were not widespread at the time, and the data was found to be varying and incomplete.

In the same case (file number 1011-13-3), the Energy Board of Appeals found that expenses for Smart Grid at the time should be kept out of benchmarking as extraordinary expenses. The Energy Board of Appeals criticized the involvement of the expenses for Smart Grid without a decision on how the expenses should be treated in the then-current grid volume model and without a decision on what should be understood in more detail by the term Smart Grid. Smart Grid has a near connection with demand response regulation, on which some emphasis is found in the latest Electricity directive. The background is to be found in the Clean Energy Package (Anchustegui and Formosa 2020, p. 90) (Hancher and Winters 2017). Should the electricity distribution network as part of the Green Transition be adapted to a greater consumption from electric cars and heat pumps, for example, and possibly electricity producers including prosumers, this could occur through a physical expansion of the electricity grid to continue to handle an increasing peak load, and/or initiatives implemented to even out the consumption over the day. ${ }^{3}$ If the network companies must invest economically rationally, it would be appropriate that income-cap regulation provide an incentive to act socioeconomically rationally in the choice between grid expansion and alternatives to this (e.g. a Smart Grid solution as demand response). This was not the case in the aforementioned case on the grid volume model. Regarding extraordinary expenses, it may be a way to modify the income-cap regulation.

Under income-cap executive order section 24, the Danish Utility Regulator can increase or revise down a network company's expense frame as a result of an injunction or modification of an injunction from an authority, including from the TSO. In EBA file number 1011-15-44 the Energy Board of Appeals did not find that the public-owned infrastructure company Metroselskabet I/S could be considered as a public authority. In urban areas, network companies have electricity network lying underneath streets and pavement. The network company does not pay to have cables lying here (so-called franchise tax). The cables lie here according to the "guest principle", under which network companies do not pay any fees but must move their cables if they get in the way of other construction projects (Mortensen 2005). Moving the cables occurs frequently. The relevant case was dealing with a large metro construction project which resulted in large expenses for the network company. The expenses for moving cables had to be borne by the network company. For example, see e.g. EBA file number 1011-10-12 and 1011-14-12. The Energy Board of Appeals as well as the Danish Utility Regulator found that cable rerouting could not be regarded as extraordinary expenses. Cable rerouting is an expected part of operating expenses that network companies have to bear. However, the Danish Utility Regulator has to make a specific assessment (EBA file number 1011-01). Furthermore, it appears from practice that orders from authorities (possible increase to the cost frame) are only considered to include individual orders and not orders or amendments that encompass the whole sector. For example, see EBA file number 1011-14-166 on data hubs and EBA file numbers 1011-13-93 and 1011-13-93 on a remote-control system.

\subsection{DE MINIMIS LIMIT}

In EBA file number 1011-14-12 the Energy Board of Appeals stated that the Danish Utility Regulator was obligated to make a specific assessment in each case regarding any omission of the benchmarking of extraordinary expenses. De minimis limits determined in the Danish Utility Regulator's practice could only be used as a guide for the exercise of discretion.

\subsection{CONSOLIDATED COMPANIES}

In EBA file number 18/00279 the question of fee revenue and expenses from net activities, but entered in a service company owned by the business group of the grid company, should be included in the regulation account. The Energy Board of Appeals, like the Danish Utility Regulator, found that the expenses and income should be included in the regulation account. Thus, leaving out mandatory licensed network activities to other companies in the business group, these cannot be kept out of the regulation account. In the relevant case, the Energy Board of Appeals decided the case based on now abolished legal pro- 
visions. However, the state of the regulation seems to be sustained. For example, see the current income-cap executive order definition of "Other income that the network company obtains from the operation of the licensed activity", cf. section 2(2) and "Operating costs", including "costs related to the activity subject to a license, which is included in the accounts and booked in companies other than the network company holding the license", cf. section 2(5). See also EBA file numbers 1011-13-3 and 18/00277.

\section{CONCLUSION AND CONSIDERATIONS}

It was hoped at the start of this research project that case law from the Energy Board of Appeals could help give an answer to what extent the Danish income-cap regulation contains elements that support the Green Transition. However, the review shows that only to a limited extent can anything of this kind be deduced. However, some elements as well as general considerations can be highlighted.

Income-cap regulation has economic efficiency as its focus. This is an important issue. Grid companies are natural monopolies. They do not have the threat of bankruptcy hanging over their heads. The complexity and number of income-cap cases before the Energy Board of Appeals indicate a not insignificant administrative burden for both the sector and the authorities. A desire to abolish this form of regulation would not be unnatural. But it is not immediately clear how to create an incentive for efficiency instead.

However, income-cap regulation is only one of several tools that the legislature can consider in order to facilitate the Green Transition. In particular, it should be ensured that the regulation does not become a barrier or counteract the Green Transition. The legislator can use other tools to support the Green Transition.

Evening out consumption over the day is an alternative to investment in cables. An extra power draw is expected to come from charging electric cars and using heat pumps. The legislator can consider technical requirements for EV charge points and heat pumps, so that these can be part of a smart grid system that can reduce the need for additional cabling.

The legislator can also consider whether solar panels should be banned in neighbourhoods with weak networks or in rural areas with low consumption and great distance to transmissions grids. There may already be socioeconomic gains from gathering solar panels in large parks and connecting these at a higher voltage level.

In section 9.2 above it was mentioned that the Energy Board of Appeals would keep costs related to Smart Grids outside the income-cap regulation. The legislator may consider whether investments that specifically relate to the Green Transition should be kept out of the revenue framework regulation. Revenue framework regulation is not necessarily the most appropriate tool when it comes to making a major overhaul of the distribution network.

The network company has a general interest in reducing its risk. It will reduce the risk if expenses within the income-cap regulation can be approved ex ante instead of ex post. For a discussion of the convenience of an ex-ante, as opposed to an ex-post approach, see Danish Utility Regulator 2020a.
Other elements besides the price regulation can also influence the investment strategy of the individual network companies. This includes ownership structure and unbundling demands, including the opportunity to draw capital and profits out of the network company. In Denmark, network companies do not necessarily have to be owner unbundled from electricity generators and electricity traders, for example. The appropriateness of this will not be considered in this paper.

\section{REFERENCES}

Baumol, W. J., Bailey, E. E. and Willig, R. D. (1977). Weak invisible hand theorems on the sustainability of multiproduct natural monopoly. The American Economic Review, 67(3), 350-365.

Danish Utility Regulator, 2019. Undersøgelse af personsammenfald i netvirksomheder, elhandelsvirksomheder og virksomheder, der direkte eller indirekte ejer elhandelsvirksomheder. https://forsyningstilsynet.dk/media/6604/rapport_undersoegelse-af-personsammenfald-i-netvirksomheder-elhandelsvirksomheder-og-virksomheder-der-direkte-eller-indirekte-ejer-elhandelsvirksomheder.pdf (accessed 22 December 2020).

Danish Utility Regulator, 2020. Analyse af elnetvirksomhedernes forrentning. https://forsyningstilsynet.dk/media/7354/analyse-af-elnetvirksomhedernes-forrentning.pdf (accessed 22 December 2020)

Danish Utility Regulator, 2020a. Grøn omstilling og økonomisk regulering. https://forsyningstilsynet.dk/media/7450/analysepapir-01_2020.pdf (accessed 22 December 2020).

Deloitte, 2013. Netselskabernes opgaver og regulering på elmarkedet i udvalgte europæiske lande. https://ens.dk/sites/ens.dk/files/El/deloitte_netselskabernes_opgaver_regulering elmarkedet.pdf (accessed 22 December 2020).

ELFOR-agreement, 2004. Agreement of 29 April 2004 between the Minister of Economy and Business regarding capital in the power sector and the securing of unbundling of transmission infrastructure. https://ens.dk/sites/ens.dk/files/EnergiKlimapolitik/elfor-aftale.pdf (accessed 22 December 2020).

Energinet, 2018. Små prosumers samspil med fremtidens energisystem i 2030. file://C:/ Users/b060969/Downloads/Prosumeres\%20samspil\%20med\%20fremtidens\%20energisystem\%20i\%202030.pdf (accessed 25 January 2021).

Hancher, L., and Winters, M. (2017). The eu winter package: briefing paper. https://fsr.eui.eu/ wp-content/uploads/The-EU-Winter-Package.pdf (accessed 22 December 2020).

Herrera Anchustegui, I., and Formosa, A. (2019). Regulation of electricity markets in Europe in light of the Clean Energy Package: prosumers and demand response, in: Hunter, T., Herrera, I., Crossley, P., \& Alvarez, G. (Eds.) (2020). Routledge Handbook of Energy Law.

Karova, R. (2012). Liberalization of Electricity Markets and the Public Service Obligation in the Energy Community (Vol. 21). Kluwer Law International.

Minto, A. (2020). Law and Economics: Theory, Methodology and Policy Application, in: Carina Risvig Hamer and Sten Schaumburg-Müller, Juraens Verden, DJØF Publishing.

Mortensen, B. O. G. (2002). Prishestemmelser og myndighedskompetencer. En redegørelse omhandlende energiforsyningslovene. https://www.sdu.dk/da/om_sdu/institutter_centre/juridisk+institut/forskning+-+ny/open_access_filer (accessed 22 December 2020).

Mortensen, B. O. G., and A. Rønne (2016). Energy Law Denmark, in: The International Encyclopaedia of Laws - Energy Law, Wolters Kluwer.

Mortensen, B. O. G. and C. R. Hamer (2020). Tilsyn, administrativ rekurs og konsekvenser af ulovlige afgorelser, in: B. O. G. Mortensen and B. Khalaf (ed.), Erhvervsforvaltningsret, 2. ed. DJØF Publishing.

Mortensen, B. O. G. and H. M. Motzfeldt (2020). Skonsudovelse, in: B. O. G. Mortensen and B. Khalaf(ed.), Erhvervsforvaltningsret, 2. ed. DJØF Publishing.

Olsen, B. E. (1999). Hvile i sig selv princippet. DJØF Publishing.

Regulation Commission of the Danish Parliament, 2014. En fremtidssikret regulering af elsektoren. https://ens.dk/sites/ens.dk/files/CO2/en_fremtidssikret_regulering_af_elsektoren_web.pdf (accessed 22 December 2020).

Sørensen, E. M. (2012). Reguleringsproblemer i elsektoren. Hvorfor slog det første forsøg med indtægtsrammeregulering fejl. Samfundsøkonomen, No1/2012. https://www.djoef-forlag.dk/ openaccess/samf/samfdocs/2012/2012_1/samf_2012_1_4.pdf (accessed 22 December 2020). 


\section{EU COURT CASES}

Case 6/64, Costa v ENEL.

Case C-393/92, Almelo and others v Energiebedrijf Ijsselmij.

\section{EBA CASES}

EBA file number 11-161 of 26 October 2004 (Himmerlands Elforsyning Net A/S). EBA file number 11-323 of 13 June 2005 (Energi Hobro Forsyning A/S).

EBA file number 11-538 of 5 May 2008 (Vestforsyning Net A/S).

EBA file number 11-539 of 5 May 2008 (Paarup El-Forsyning). EBA file number 11-540 of 5 May 2008 (Kongerslev Elnet ApS).

EBA file number 1011-1 of 17 November 2008 (DONG Energy City Elnet A/S).

EBA file number 11-273 of 20 April 2009 (Viby Net A/S).

EBA file number 1011-277 of 20 April 2009 (Dansk Energi).

EBA file number 1011-331 of 20 April 2009 (NOE Net A/S et al).

EBA file number 1011-346 of 18 May 2010 (NV Net A/S et al).

EBA file number 1011-405 of 24 September 2010 (Hammel Elforsyning Net A/S).

EBA file number 1011-10-9 of 6 June 2011 (Thy-Mors Energi A/S et al).

EBA file number 1011-10-12 of 6 June 2011 (KE Transmission A/S).

EBA file number 1011-10-8 of 5 September 2011 (NOE Net A/S).

EBA file number 1011-11-76 of 7 May 2012 (Frederikshavn Forsyning A/S).

EBA file number 1011-11-78 of 7 May 2012 (Forsyning Helsingør Elnet A/S).

EBA file number 1011-11-79 of 7 May 2012 (ENV Net A/S).

EBA file number 1011-11-80 of 7 May 2012 (NRGi Net A/S).

EBA file number 1011-11-26 of 13 June 2012 (Dansk Energi).

EBA file number 1011-13-3 of 19. August 2013 (Dansk Energi).

EBA file number 1011-13-91 of 23 April 2014 (NRGi Net A/S).

EBA file number 1011-13-93 of 12 May 2014 (Viby Net A/S).

EBA file number 1011-14-12 of 27 June 2014 (Dansk Energi).

EBA file number 1011-14-52 of 27 June 2014 (Dansk Energi).

EBA file number 1011-15-4 of 9 September 2015 (DONG Energy Eldistribution A/S).

EBA file number 1011-15-8 of 9 September 2015 (SK Elnet A/S).

EBA file number 1011-14-166 of 28 October 2015 (Energi Fyn Net A/S).

EBA file number 1011-15-44 of 29 June 2016 (DONG Energy).

EBA file number 18/00211 of 13 June 2018 (Hjerting Transformatorforening A.m.b.a.).

EBA file number 18/00359 of 3 August 2018 (Radius Elnet A/S).

EBA file number 18/00206 of 17 September 2018 (NRGi Net A/S).

EBA file number 18/00276 of 24 September 2018 (Vores Elnet A/S).

EBA file number 18/00277 of 20 December 2018 (Vores Elnet A/S).

EBA file number 18/00278 of 20 December 2018 (Evonet A/S).

EBA file number 18/00281 of 21 December 2018 (Cerius A/S).

EBA file number 18/00279 of 1 March 2019 (Radius Elnet A/S).

EBA file number 18/03884 of 24 June 2020 (Vores Elnet A/S).

\section{LEGISLATION}

Electricity Supply Act: Latest Act no. 119 of 6 February 2020.

- Repealed Act no. 54 of 25 February 1976

- Repealed Act No. 375 of 2 June 1999.

- Bill no. L 234 of 29 April 1999.

- Act no. 662 of 8 June 2017 regarding amendments of among others the Danish Energy Supply Act.

- Bill No. L 180 of 29 March 2017 regarding amendments of among others the Danish Energy Supply Act.
Energy Net Act: Latest Act no. 118 of 6 February 2020.

- Bill No. L 115 of 26 February 2020 regarding amendments of among others the Danish Energy Net Act.

Heat Supply Act: Repealed Act no. 258 of 8 June 1979.

Monopoly Act: Repealed Act no. 102 of 31 March 1955.

Price and Profits Act: Repealed Act no. 59 of 15 February 1974

\section{EXECUTIVE ORDERS}

Executive Order no. 944 of 29 October 2001 on income-caps and opening balances for grid companies and transmission companies with electricity supply grids of $150 \mathrm{kV}$ and below.

Executive Order no. 432 of 6 June 2002 amending Executive Order on income-caps and opening balances for grid companies and transmission companies with electricity supply grids of $150 \mathrm{kV}$ and below.

Executive Order no. 1148 of 15 December 2003 amending Executive Order on income-caps and opening balances for grid companies and transmission companies with electricity supply grids of $150 \mathrm{kV}$ and below.

Executive Order no. 899 of 30 August 2004 on income-caps for grid companies and transmission companies.

Executive Order no. 1520 of 23 December 2004 on income-caps and opening balances for grid companies and regional transmission companies regulated by the electricity supply act.

Executive Order no. 151 of 10 March 2005 amending Executive Order on income-caps for grid companies and regional transmission companies regulated by the electricity act.

Executive Order no. 1027 of 2 November 2009 on income-caps for grid companies and regional transmission companies regulated by the electricity supply act.

Executive Order no. 1227 of 10 December 2009 on income-caps for grid companies and regional transmission companies regulated by the electricity supply act.

Executive Order no. 1294 of 24 November 2010 on income-caps for grid companies and regional transmission companies regulated by the electricity supply act.

Executive Order no. 335 of 15 April 2011 on income-caps for grid companies and regional transmission companies regulated by the electricity supply act.

Executive Order no. 195 of 4 March 2016 on income-caps for grid companies and regional transmission companies regulated by the electricity supply act.

Executive Order no. 857 of 28 June 2017 amending Executive Order on income-caps for grid companies and regional transmission companies regulated by the electricity supply act.

Executive Order no. 1594 of 18 December 2017 on income-caps for grid companies.

Executive Order no. 969 of 27 June 2018 on income-caps for grid companies.

Executive Order no. 1366 of 28 November 2018 amending Executive Order on income-caps for grid companies.

\section{WEB REFERENCES}

Energy Board of Appeals' public website: https://ekn.naevneneshus.dk/

- The EBA cases cited in the text above can be found at this site by searching for the file number. This also applies also older cases for which the file number system is different from the current system. The last search has been repeated on 10 October 2020 . 